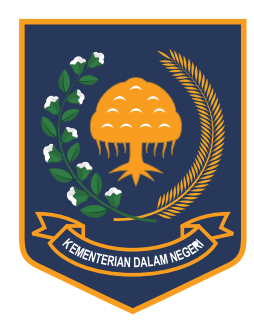

JURNAL BINA PRAJA

e-ISSN: 2503-3360 | p-ISSN: 2085-4323

Accreditation Number

21/E/KPT/2018

http://jurnal.kemendagri.go.id/index.php/jbp/index

\title{
The Impact of Government Policy REgarding WASTE MANAgEMENT in Tapin Districts South Kalimantan Province
}

\author{
Riry Magriaty ${ }^{1, *}$, Kukuh Murtilaksono $^{2}$, Syaiful Anwar $^{3}$ \\ 1,2,3 IPB University, Department of Land Science and Resources, \\ Dramaga Bogor 16680, Indonesia
}

Received: 22 January 2020; Accepted: 19 May 2020; Published online: 28 May 2020

DOI: $10.21787 / j b p .12 .2020 .89-99$

\begin{abstract}
The support of the local government and all social levels in the community is the key to successful waste management systems. Waste is mainly produced by community households. Deficient treatment and disposal severely pollute the environment. Therefore, the community must have an active role in protecting the environment. Regulation is an important aspect of policies and programs for the implementation of the waste management system to ensure that lower regulation is in line with the higher policies made by the central government. The objective of the study was to review regional regulation on waste management, comparing them to the central regulation government of waste policy, and analyze the implementation of the waste management system in the region. Content analysis was used to analyze the waste management of regional government policy. The implementation of waste management systems was analyzed using primary data obtained through observation. The secondary data was obtained by classifying the waste generation in tabular data calculated from the average of waste production by household per capita to the number of the population each subdistrict. The result indicated that the Regulation of Tapin District No. 6 of 2015 on the waste management system is in line with the central government waste policy. The implementation of waste management systems had not been carried out effectively by the regional government. The district generated solid waste at 93.3 tons each day and can only manage $27.21 \%$ in 4 subdistricts of urban settlement areas. The solid waste generation can be classified into five classes. Most are in the low and very low waste generation class. The very high generation class was in subdistricts, which have the highest population density in the region.
\end{abstract}

Keywords: Content Analysis, Waste Policy, Waste Management System.

\section{INTRODUCTION}

Waste is a problem caused by most countries in the world, including Indonesia, which has a fairly complex waste problem due to the large population (Widyarsana \& Zafira, 2015). Indonesia is the 4th most populous country in the world, with more than 265 million people in 2018 and a population growth rate of $1.33 \%$ per year (BPS Kabupaten Tapin, 2020). The population greatly influences the volume of waste because everyone is a source of waste generation. At the time of the study, Tapin District's population was 191,370 persons, with a growth rate of $1.19 \%$ per year (BPS Kabupaten Tapin, 2020). The population of Tapin District is projected to continue to increase, with such growth rate, it would reach more than 200,000 persons by 2025 . Population growth increases the number of settlements and the amount of waste because the waste generated is positively correlated to the number of populations in an area.

On the other hand, with the changing of times, civilizations, lifestyles, and income levels, the waste produced in an overwhelming amount, diverse, and difficult to decompose naturally, causing nature to unable to process the waste (Wahyono, 2018). Based on research by Jambeck et al. (2015), with 187.2 million tons/year of plastic waste, is number two in the world's largest producer of plastic waste after China. Environmental Statistics data shows that the amount of waste generation in Indonesia reaches 65.2 million tons/year and is projected to reach 68

\footnotetext{
* Corresponding Author

Phone : +62811 5015253

Email : rieriepwl18@gmail.com
} 
million tons in 2019, which contains 9.52 million tons of plastic waste that is difficult to decompose (BPS Indonesia, 2017). A good waste management process needs to be carried out to minimize problems arising from waste. Wirawan et al. (2018) stated that one of the factors causing water pollution is the presence of domestic wastewater from the households directly into rivers or into uncontrolled land as a result of low public awareness to protect the environment.

The community's low awareness was a result of its differences in the social characteristics and perspective of waste management, and the lack of serious involvement of the local government in dealing with the overall problem of environmental pollution in the area. In line with this situation, Rahman (2013) stated that waste management might vary in an area as well as the behavior of the people.

With an area of 2,174.95 $\mathrm{km}^{\wedge} 2$, most of the area of Tapin District is dominated by settlements that are mostly located on the riverbanks. The landscape in this area consists of the Barito watershed (DAS) that has tributaries spread across several subdistricts, namely the Muning River, Tatakan River, Halat River, and Gadung River. All human activities that live on the riverbanks have an impact on the environment. Data shows that the water quality index in the Tapin River has declined from year to year.

In 2018, the Water Quality Index (IKA) in the Tapin river was 60.67, while in 2019, the IKA in the Tapin river was 54.67, or in a polluted condition (DLH Kabupaten Tapin, 2020).

So far, the handling of waste problems has only been carried out in urban areas, which is a very small coverage compared to the whole area. Since the enactment of Regional Regulation No. 6 of 2015 on Waste Management, Tapin District has only been able to manage 9,269 tons of waste generated in 2017 or $27.21 \%$ of the total generated domestic and nondomestic waste. PTMP data showed that the fleet of garbage transport services can only serve residents in urban areas in 4 (four) districts, namely the Districts of North Tapin, Lokpaikat, South Tapin, and Binuang in certain settlement areas. Thus, there were 9 subdistricts in Tapin District that were not covered by the waste transportation fleet.

Law No. 18 of 2008 on Waste Management mandates that waste management needs to be carried out comprehensively and integrated from upstream to downstream to provide economic benefits, healthy for the community, safe for the environment, and can change people's behavior (Law No. 18 of 2008 on Waste Management, 2008). Regional Regulation No. 6 of 2015 on Waste Management was made as the legal basis in the implementation of a waste management system in Tapin District. The Solid Waste Management Performance Development Program was established with an APBD value of Rp7,456,355,200 or $61.80 \%$ of the total budget of the Office of the Environment (DLH), where most of the budget was allocated to the handling of urban waste.

Since the issuance of the 2013 garbage disposal master plan, the DLH performance on the waste management system is very low. On the other hand, the capacity of the Hatiwin Final Disposal Area (TPA) can only accommodate $42,612 \mathrm{~m} 3$ of waste. In 2018, the amount of waste transported to the TPA reached $46,873 \mathrm{~m} 3$, while in 2019 , the amount of waste sent to the TPA reached $11,075,200$ tons or $33,561,212$ $\mathrm{m} 3$. The large amount of waste that is not managed at the source and the limited carrying capacity of the waste management facility has caused Hatiwin TPA to be overloaded.

The integrated waste management concept is taking the sustainable dimension into account. It requires an integrated system which pay attention to aspects of legal regulations, institutions, operational techniques, financing, and the role of the community. According to Damanhuri \& Padmi (2019), these are aspects that influence the success of waste management, along with aspects of stakeholders, waste management, and others. Thus, the waste management in the region must be carried out jointly between the local government and all levels of society to ensure its success. Regulatory aspects, as seen from regulations/policies and programs, are influential aspects and need to be analyzed further to find out whether central policies have been made into regulations in the regions.

The amount of waste generated from an activity will determine the amount of waste that must be managed (Damanhuri \& Padmi, 2019). Meanwhile, the actual condition of waste management can be used as a baseline for planning by understanding the capacity and adequacy of the physical carrying capacity of the current waste management infrastructure.

Based on the description, the objectives of the study were as follows: (1) Analyzing the alignment of Tapin District Regulation No. 6 of 2015 toward Law No. 18 of 2008 concerning on management; (2) Analyzing the actual waste handling in Tapin District.

\section{METHOD}

\section{A. Location}

This study was conducted in Tapin District, South Kalimantan Province, which is located at latitude: -3.009007 and longitude: 114.975418 . This area covers 12 subdistricts, 9 urban villages, and 126 villages, as shown in Figure 1. 


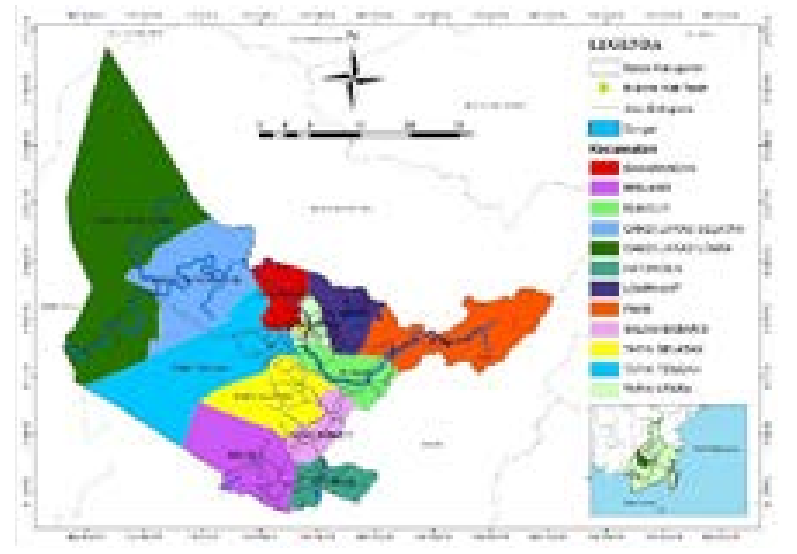

Figure 1. Map of The Administrative Boundary of The Study Locations

\section{B. Types and Sources of Data}

The types and sources of data used in this study were primary and secondary data. The primary data was collected form field surveys and observations in 2019 on the existing waste management system. The secondary data was collected from the related government institutions, which consist of the related regulations on waste management from the Secretary of Tapin District, data on population form the BPS-Statistic Indonesia of Tapin District, the average the community's waste generation form the Environmental Office of Tapin District.

\section{Data Analysis Techniques}

\section{1) Content Analysis}

Content analysis was conducted to assess the conformity of Regulation of Tapin District No. 6 of 2015 on Waste Management to Law No. 18 of 2008 on Waste Management.

The analysis was important to be carried out because the regional regulation was issued as the basis of the district government's policies in waste management, such as region's programs, activities, and budget.

Content analysis was conducted by Jaya et al. (2010) on the implementation of the Bandar Lampung City's policy against Law No. 18 of 2008 regarding Waste Management by tabulating key questions regarding the contents of the law on waste management concerning household waste management. Andriyan (2019) conducted content analysis by noting the symbols or messages or key words, key sentences, legal principles used, articles and paragraphs that form the core of a regional regulation on Islamic law.

A descriptive approach was carried out with the initial step of formulating the objectives of the analysis. Keywords were made to enable the concepts to be measured, by making a list of questions so that
Table 1.

Waste Management Aspects and Keywords for Content Analysis in Regional Regulation No. 6 Of 2015

\begin{tabular}{ll}
\multicolumn{1}{c}{ Aspects } & \multicolumn{1}{c}{ Keywords } \\
\hline Management and Manager & $\begin{array}{l}\text { Principles, goals, waste } \\
\text { reduction, waste management, } \\
\text { specific waste management, } \\
\text { rights, obligations, and } \\
\text { financing }\end{array}$ \\
\hline $\begin{array}{l}\text { Stakeholder involvement } \\
\text { (regional government, } \\
\text { community, and } \\
\text { businesspeople). }\end{array}$ & $\begin{array}{l}\text { Duties, obligations, and } \\
\text { authority }\end{array}$ \\
\hline $\begin{array}{l}\text { Collaboration and partnership } \\
\text { Cooperation between regions } \\
\text { and partnerships }\end{array}$ \\
\hline
\end{tabular}

they could be interpreted, and conclusions could be drawn about their conformity. The content analysis of the Regional Regulation No. 6 of 2015 on Waste Management was carried out as the following:

1. A tabulation of a list of key questions was created about the articles in Regional Regulation No. 6 of 2015 related to aspects of waste management, which are the aspect of management and managers, stakeholder involvement, and cooperation and partnerships.

2. Table 1 presents the keywords that contain the aspects most related to waste management.

3. A conclusion was drawn based on the analysis, whether in general, the articles in Regional Regulation No. 6 of 2015 have accommodated aspects of waste management properly and are in line with the articles contained in Law No. 18 of 2008.

\section{2) The Actual Waste Management}

The analysis of actual waste management is conducted using descriptive analysis methods to determine the potential for waste generation, its management system, the capacity, and distribution of waste management facilities owned by district governments in urban and rural areas. Primary data were obtained from field surveys and observations to find out the capacity of each waste reduction infrastructure spread throughout the region as well as its distribution. This calculation is based on the study by Paramita et al. (2018), which calculated the amount of waste generation in Depok City. The amount of waste generation generated in each village/urban village was calculated based on the average value of generated waste based on the 2017 garbage generation survey, which is 2.5 liter/day or equivalent to $0.5 \mathrm{~kg} /$ day. 
The composition of waste in the Tapin District consists of $57.29 \%$ organic waste and $42.71 \%$ inorganic waste. Based on the above information, the amount of waste generated by each person per year in each village was calculated as the following:

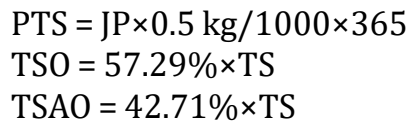

Where:

PTS : Potential Waste Generation

TSO : Organic Waste Generation (tons)

TSAO : Inorganic waste generation

JP : Number of People

The waste generation potential is classified into 5 (five) classes: very high, high, medium, low, and very low. The formula used to calculate the class interval for potential solid waste generation are the following:

$\mathrm{IK}=\frac{\mathrm{TS} \text { Max }-\mathrm{TS} \text { Min }}{\mathrm{KTS}}$

Where:

IK : Class Interval

TS Max : Maximum Waste Generation

TS Min : Minimum Waste Generation

KTS : Number of Waste Generation Potential Class

\section{RESULTS AND DISCUSSION}

\section{A. The Alignment of Tapin District Regulation No. 6 of 2015 Toward Law No. 18 of 2008 Concerning on Management}

Regulation is one of the important instruments that will have an impact on waste management systems and policies implemented in an area. Regulations are made for law enforcement and certainty, clarity of roles, responsibilities, and authority of stakeholders for sustainable waste management. The objectives are to overcome the complicated waste problem through comprehensive waste management from upstream to downstream to create public health, safe for the environment, provide economic benefits, and can change the culture of the community.

Law No. 18 of 2008 is a regulation that governs waste management in Indonesia. Law No. 18 of 2008 stated that the implementation of waste management in the regions is further regulated by regional regulations in accordance with their authority (Law No. 18 of 2008 on Waste Management, 2008). The issuance of Regional Regulation No. 6 of 2015, which took effect since June 5, 2015, is used as the regulation and legal umbrella for the implementation of waste management systems in the regions to create a sustainable waste management system (Regional Regulation No. 6 of 2015 on Waste Management, 2015).

In this study, the key questions used to analyze the Regional Regulation No. 6 of 2015 are:

1. What are the principles, objectives, waste reduction, waste handling, and specific waste management, rights and obligations, financing, compensation, and supervision related to waste management in Tapin District?

2. Is there involvement or participation of related parties/ stakeholders in the implementation of the waste management system (including the aspects of the duties and obligations of the Tapin district government, rules regarding community participation in waste management and businesspeople) stated in the regulation?

3. Is there inter-regional cooperation and partnerships stated in the regulation?

Based on the results of the content analysis, there are at least 24 articles related to the basic aspects of waste management.

Table 2 shows that from the key questions regarding waste management on the aspects of management and managers in waste management, 14 articles are aligned.

The regulation caused waste management in Tapin District to be divided into 3 (three) activities, namely waste reduction, waste management, and hazardous and toxic waste management (DLH Kabupaten Tapin, 2018). The Financing aspect contained in article 38 paragraphs 1 and 2 states that the district government finances the implementation of waste management from the regional budget (APBD). Based on the 2019 Tapin District Government Agency Performance Accountability Report, in 2018, the budget disbursed for waste management reached Rp7,456,355,200, with a budget absorption rate of $95.3 \%$ or Rp7,107,703,500 of the total program budget in the Waste and LB3 (Toxic and Hazardous Waste) management. Most of the budget was still not optimally allocated, because it is only concentrated on urban waste management activities, which reached $61.3 \%$ of the total budget or Rp4,572,405,800.

One of the keys to success in a sustainable waste management system is the involvement of stakeholders. Based on Table 2, it can be seen that the aspects of the obligation of every stakeholder in the waste management system were regulated in several articles. These articles explain the stakeholders' obligations in reducing and handling 
Table 2.

The Alignment of Waste Management Aspect in Regional Regulation No. 6 of 2015

\begin{tabular}{|c|c|c|}
\hline $\begin{array}{c}\text { Aspect of } \\
\text { Management and } \\
\text { Manager in Law No. } \\
18 \text { of } 2008\end{array}$ & $\begin{array}{l}\text { Number } \\
\text { of Articles }\end{array}$ & $\begin{array}{l}\text { Articles in line with Regional } \\
\text { Regulation No. } 6 \text { of } 2015\end{array}$ \\
\hline Principles & 1 & Article 2 \\
\hline Objectives & 1 & Article 3 \\
\hline Waste Reduction & 2 & Article 8,9 paragraphs 1 \\
\hline Waste Management & 1 & Article 10 \\
\hline Waste Processing & 1 & Article 19 \\
\hline Rights & 1 & Article 22 paragraph 1 \\
\hline Obligations & 4 & $\begin{array}{l}\text { Article } 23 \text { paragraph } \\
\text { 1, Article } 24 \text {, Article } 25 \\
\text { paragraph } 1 \text {, Article } 26\end{array}$ \\
\hline Financing & 1 & Article 38 paragraph 1 and 2 \\
\hline Compensation & 1 & Article 39 paragraph 1 and 2 \\
\hline Supervision & 1 & Article 47 paragraph 2 \\
\hline
\end{tabular}

Source: Content Analysis Result on The Regional Regulation No. 6 of 2015 on Waste Management

waste in an environmentally sound manner. The intended stakeholders are individual household waste producers (community), household-like waste producers, activity organizers (local government), and managers of an area (businesspeople).

Table 3 shows that eight articles are regulating the involvement of various parties in waste management. The role of the Tapin District Government, as a stakeholder in the formulation of policies and regulations on waste management in the area, was regulated in detail in three articles, namely regarding the duties, obligations, and authorities. In its application, the local government, through DLH Tapin District, has implemented the rules contained in Article 5 by carrying out the management of waste and facilitating the provision of infrastructure and facilities in waste management. One of the successes of waste management in the area is from the institutional aspect of waste management. This is in line with the study by Puspasari \& Mussadun (2016), which states that waste management was less than optimal due to the weak institutional relations between the government and the community.

In this law, community participation is regulated in three articles, and there is at least one special article governing aspects of community involvement
Table 3.

The Alignment of Regional Regulation No. 6 of 2015 on the Aspect of Stakeholders

\begin{tabular}{|c|c|c|}
\hline $\begin{array}{l}\text { Aspect of } \\
\text { Stakeholders' } \\
\text { Involvement in Law } \\
\text { No. } 18 \text { of } 2008\end{array}$ & $\begin{array}{l}\text { Number } \\
\text { of Articles }\end{array}$ & $\begin{array}{l}\text { Articles in line with Regional } \\
\text { Regulation No. } 6 \text { of } 2015\end{array}$ \\
\hline $\begin{array}{l}\text { Regional } \\
\text { Government }\end{array}$ & 3 & $\begin{array}{l}\text { Article } 5 \text {, article } 6 \text { paragraph } \\
1 \text {, article } 23 \text { paragraph } 5 \\
\text { and } 6,\end{array}$ \\
\hline $\begin{array}{l}\text { Community } \\
\text { Involvement }\end{array}$ & 3 & $\begin{array}{l}\text { Article } 41 \text {, Article } 42 \\
\text { paragraph } 1-3, \text { Article } 43 \\
\text { paragraph } 1-7\end{array}$ \\
\hline $\begin{array}{l}\text { Businesspeople } \\
\text { Involvement }\end{array}$ & 2 & $\begin{array}{l}\text { Article } 13 \text { paragraph } 1 \text { and } \\
\text { Article } 26\end{array}$ \\
\hline
\end{tabular}

Source: Content analysis result on the Regional Regulation No. 6 of 2015 on Waste Management

in waste management. The forms and procedures for community participation were regulated in three articles, namely procedures for increasing community participation, as well as community functions in the waste management system. DLH Tapin District has conducted socialization to increase community participation. On the other hand, the lack of budget for this activity causes a low level of community participation, especially for people in rural areas who have not been reached by waste services.

The key to success in increasing community participation might be from internal and external factors that can influence attitudes, perceptions, and levels of participation in waste management. As stated in a study by Jaya et al. (2010) that the community characteristic is a very strategic variable in the waste management program. In line with that study, Nugraha (2017) also mentioned that participation by the community in waste management is inseparable from individual characteristics and the influence of the individual's external environment.

The participation of businesspeople in the waste management system has not been specifically regulated. However, there are two articles regarding the responsibilities and obligations of businesspeople in the regions. The management of an area is responsible for the waste generated in the business area and has a role in providing waste sorting facilities in the area. The role of businesspeople as stakeholders are also regulated in one article on the management of regional waste, which is the responsibility of the management of an area. However, there is no detailed explanation of the procedures for the participation of businesspeople in the waste management system. 
Table 4.

Content Analysis Result on The Aspect of Stakeholders' Involvement in The Regional Regulation No. 6 of 2015 on Waste Management

\begin{tabular}{|c|c|c|c|}
\hline $\begin{array}{c}\text { Aspect of } \\
\text { Stakeholders' } \\
\text { Involvement }\end{array}$ & $\begin{array}{c}\text { Regional } \\
\text { Government }\end{array}$ & Community & Businesspeople \\
\hline Principles & $v$ & & \\
\hline Objectives & $v$ & & \\
\hline $\begin{array}{l}\text { Waste } \\
\text { Reduction }\end{array}$ & $v$ & $v$ & $v$ \\
\hline $\begin{array}{l}\text { Waste } \\
\text { Management }\end{array}$ & $v$ & v & $v$ \\
\hline $\begin{array}{l}\text { Waste } \\
\text { Processing }\end{array}$ & $v$ & & \\
\hline Rights & $v$ & $v$ & $v$ \\
\hline Obligations & $v$ & v & $v$ \\
\hline Financing & $v$ & & \\
\hline Compensation & $v$ & & \\
\hline Supervision & $\mathrm{v}$ & & \\
\hline
\end{tabular}

Source: Content Analysis Result on the Regional Regulation No. 6 of 2015 on Waste Management

In reality, article 26 was not fully implemented. The management of the area, such as markets and industries that produce non-domestic waste or even the toxic and hazardous waste, and residential areas that produce domestic waste, did not provide waste sorting facilities. The management of areas such as markets, residential areas, and industries used the Waste Management and LB3 Unit to carry out the collection-transport-disposal of the waste produced in their area. This should be of particular concern to the regional government that has the authority to enforce the law on the handling of specific waste of an industrial area, as well as businesses, especially in terms of providing temporary collection location (TPS), integrated temporary collection location (TPST), or waste processing location using the 3R principle (TPS3R) in their respective areas.

Table 4 shows the stakeholder involvement in the basic aspects of waste management. The results of the analysis show that in general, the regional government has a role in all aspects of waste management, while the community and businesspeople have rights and obligations, as well as having an involvement in the handling and reducing waste.
Table 5.

The Total Number of Articles in Regional Regulation No. 6 of 2015 Regulating Cooperation and Partnership

\begin{tabular}{ccc}
$\begin{array}{c}\text { Aspect of } \\
\text { Cooperation and } \\
\text { Partnership in Law } \\
\text { No. } \mathbf{1 8} \text { of } \mathbf{2 0 0 8}\end{array}$ & Number of Articles & $\begin{array}{c}\text { Articles in line with } \\
\text { Regional Regulation } \\
\text { No. } \mathbf{6} \text { of } 2015\end{array}$ \\
Cooperation & 1 & $\begin{array}{c}\text { Article } 36 \text { paragraph } \\
1 \text { and } 2\end{array}$ \\
\hline Partnership & 1 & Article 37 paragraph \\
& & 1 and 2 \\
\hline
\end{tabular}

Source: Content Analysis Result on the Regional Regulation No. 6 of 2015 on Waste Management

Table 5 shows the number of articles related to cooperation and partnerships of the regional governments and waste management business entities. Stakeholders related to this aspect consist of district government and waste management business entities. The form of cooperation referred to is cooperation in a joint venture as well as a partnership with waste management entities in the implementation of waste management in the regions, which is outlined in an agreement.

Based on the results of the content analysis, in general, the basic aspects of waste management in Regional Regulation No. 6 of 2015 is in line with Law No. 18 of 2008. Several issues are not regulated in detail, in terms of the participation of businesspeople to be more actively involved in organizing waste management, especially for the concrete efforts to reduce waste.

Several other regulations were issued relating to waste management to strengthen the existing regulation. In 2018, the regional government issued Tapin District Head Regulation No. 22 of 2018 concerning Regional Policies and Strategies in the Management of Household Waste and Waste Similar to Household Waste that aims to create policies and strategies in reducing and handling waste generation with a target of $30 \%$ reduction on waste generation and $70 \%$ managed waste by 2025 . One of the efforts of the district government to achieve the target was the issuance of Tapin Regent Regulation Number 06 of 2019 concerning Reduction of Use of Plastic Bags, which became effective in January 2020.

\section{B. The Actual Waste Management in Tapin District}

The waste management was carried out by DLH Tapin District as an agency that has the main tasks and functions in the field of waste management. Management of household waste and waste similar 
to household waste was conducted by reducing and processing the waste. DLH Tapin District performs this function through the Waste and Toxic and Hazardous Waste Management Unit with the ability to manage $27.2 \%$ of waste, which represented the management capacity of 25.4 tons/day from 93.3 tons of waste produced.

The waste management system in Tapin District was using an individual and communal waste collection-transport-disposal system. The indicator was that, out of the 93.3 tons of waste produced each day, the amount of waste transported to the Hatiwin TPA was, on average, 23.6 tons/day, which was more than the waste processed in waste reduction facilities of only 0.69 tons/day. The reduction that can be conducted is 0.45 tons/day of organic waste, and 0.24 tons/day of inorganic waste conducted at the waste reduction facility every day, while the remaining 67.94 tons is handled by the community. The sub-optimum efforts of the DLH Tapin District to address the untreated waste is a challenge to increase its service coverage.

Suntari et al. (2018) stated that community participation is an important aspect of the effort to reduce waste at the source (upstream). In line with the study, the importance of community participation in managing waste at the source has a significant impact on the utilization of the result and the processing of waste. The results of the analysis of participation show that low participation in certain areas is an obstacle in reducing waste sent to Hatiwin TPA. Most of the community did not sort their waste, while the regional government also fail to provide the designated bins in several areas. Furthermore, there was a substantial gap between the budget for waste reduction and actual waste managed by the DLH Tapin District.

Another obstacle faced by the District government is the lack of facilities and infrastructure. The socialization and training to the community to change their environmental culture were also lacking. With a very small number of TPS3R facilities, the amount of waste reduction was very limited. Tapin Main Waste Bank was also only able to reduce inorganic waste by 0.24 tons/day. Nevertheless, the existence of TPS3R and the garbage bank is an effort to increase community participation to reduce waste while providing economic benefits for the community as the largest source of household waste producers.

TPS3R and the Main Waste Bank are organic and inorganic waste treatment facilities in Tapin District. Seruyaningtyas et al. (2017) hat, in principle, the operation of the 3R Temporary Waste Management Site (TPS) is directed at the concepts of Reduce, Reuse, and Recycle, where efforts are made to reduce waste from the source by using organic waste as compost raw material, and inorganic components as secondary materials for industrial activities such as plastic, paper, metal, glass, and others.

At the main waste bank, inorganic waste is more than organic waste. Of the three existing TPS3R units, one TPS3Rs is not actively operating every day, namely TPS3R located in Bitahan Village, Lokpaikat subdistrict. This, of course, becomes an obstacle in meeting the waste reduction target in the district strategic policy document, which must be met within a certain period of time. Constraints faced in general were the lack of coordination from DLH to TPS3R managers so that the TPS3R management did not carry out their duties as they should. Also, the machine production capacity without modification causes the limitation of organic waste to be processed, so that the compost produced is not comparable with the operational costs.

Tapin District carries out waste management in urban areas that have an indirect individual collection system. Waste was directly collected and transported using garbage transportation to TPS or TPST, which is spread in several areas in urban areas and then transported to the Hatiwin TPA.

Coverage area planning for waste management can be conducted by referring to a baseline of the waste generation analysis so that the potential waste generation for each village/urban village is known. According to Damanhuri \& Padmi (2019), waste generation is the amount of waste generated from an activity that will determine the amount of waste to be managed. Waste generation is used to develop program planning and management systems. Waste generation is stated in units of weight $(\mathrm{kg} /$ person/ day) or volume (liters/person/day). The community characteristics and waste generation are some of the factors that can predict the composition of waste produced by households (Dobiki, 2018).

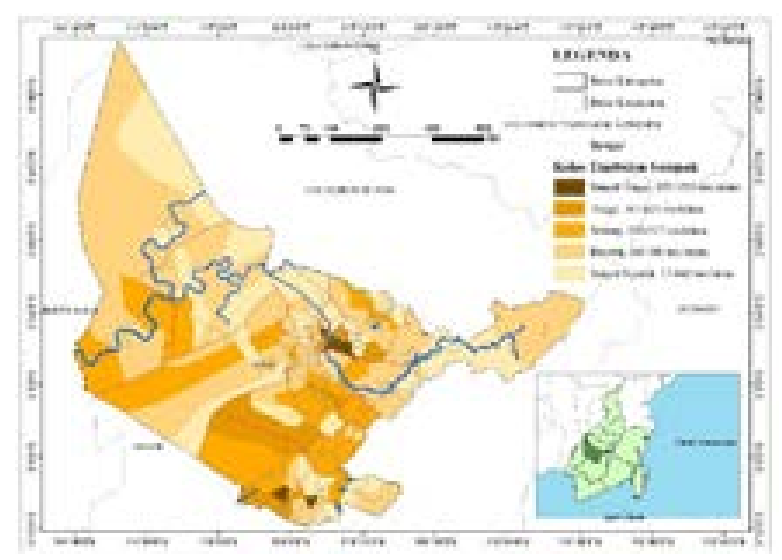

Source: Result of data analysis in 2019

Figure 2. The Grouping of Tapin District's Waste Generation 


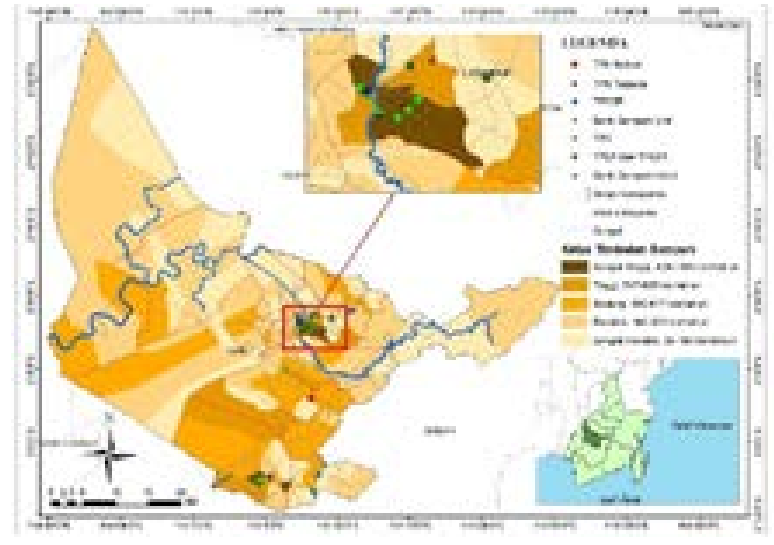

Source: Result of data analysis in 2019

Figure 3. Spatial Distribution of Waste Infrastructure of Tapin Districts

The analysis results are then used as a basis for determining the management of organic and inorganic waste With a known amount of organic and inorganic waste generation in an area, the current environmental carrying capacity in each village can be ascertained, and the regional government can determine the infrastructure that needs to be provided.

The potential waste generation in an area is used as a basis for regional service planning. Figure 2 shows a map of the waste generation of the district from the result of data analysis. The data analysis shows that the waste generation in Tapin District can be grouped into 5 classes.

The classes are the following:

1. Very low (between 33-160 tons/year)

2. Low (between 160-300 tons /year)

3. Medium (between 300-517 tons/year)

4. High (between 517-825 tons/year), and

5. Very high (between 825-1,350 tons/year).

Waste generation in Tapin District is dominated by low waste generation in rural areas. This is a marginal group, as such intervention from the regional government is needed for overall waste management to reduce the impact of pollution caused by population activities, especially in residential areas that are in the watersheds area or upstream.

Figure 3 shows the distribution map of Tapin District waste management infrastructure. Field observations show that infrastructure in this region generally consists of TPS and TPST as communal waste disposal infrastructure, waste banks as inorganic waste reduction facilities, and TPS3R as infrastructure for collection, sorting, reuse, and recycling of an area, and TPA or landfill. Waste management infrastructures were mostly located in urban areas that have very high and high levels of waste generation, such as in urban villages of Rantau Kiwa, Rangda Malingkung, Kupang, and Binuang. However, it appears that there were gaps in the provision of infrastructure in several other areas that did not have a waste management infrastructure.

The availability of waste management infrastructure is important for the principles of justice and equity in all areas of the district. The district environmental management infrastructure network system for the development of the waste management system network planned in the 2012-2034 Regional Spatial Plan can at least be realized by the regional government. The development of providing adequate integrated infrastructure for processing organic and inorganic waste aims to reduce the burden of the Hatiwin TPA as the landfill in Tapin District.

Waste management of an urban area is in the District of North Tapin, with a total 7,486 households that generated a total of 4,706 tons/year or equivalent to 12.9 tons/day. The potential organic waste generation is 2,696 tons/year, while the potential inorganic waste generation is 2,020 tons/year . The highest waste generation was in urban village of Rangda Malingkung, which is $26.69 \%$ of the total waste generation, while the lowest waste generation was in Badaun Village.

The waste generation in North Tapin Subdistrict was grouped into four classes (Very High, High, Low, and Very Low). The very high waste generation class was in urban villages of Rangda Malingkung and Rantau Kanan with a total of 825-1350 tons/year. The high waste generation class, between 517-825 tons/year, was in urban villages of Kupang and Rantau Kiwa. The low waste generation class, between 160300 tons/year, was located in the villages of Perintis Raya, Antasari, and Antasari Hilir. The very low waste generation class, between 33-160 tons/year, was in the villages of Banua Halat Kiri, Lumbu Raya, Keramat, Banua Halat Kanan, Babah Jingah, Kakaran, Badaun, Banua Hanyar Hulu, and Banua Hanyar.

North Tapin Subdistrict is one of the districts that has been covered by the regional government's waste management services. Initially, the regional government only provided waste management services in North Tapin's urban areas.

Based on the waste management masterplan of the Urban Planning and Sanitation Office (Dinas Tata Kota dan Kebersihan) of Tapin City in 2013, there were 22 TPS scattered in the urban areas, $31.82 \%$ of them were in damaged condition, $27.2 \%$ were in moderately damaged condition, and $40.9 \%$ or 9 TPS units were in good condition. Field observation was carried out based on these preliminary data to gather the actual condition of the waste management facilities owned by the Regional Government. Figure 4 shows one of the TPS facilities in the urban area. The 


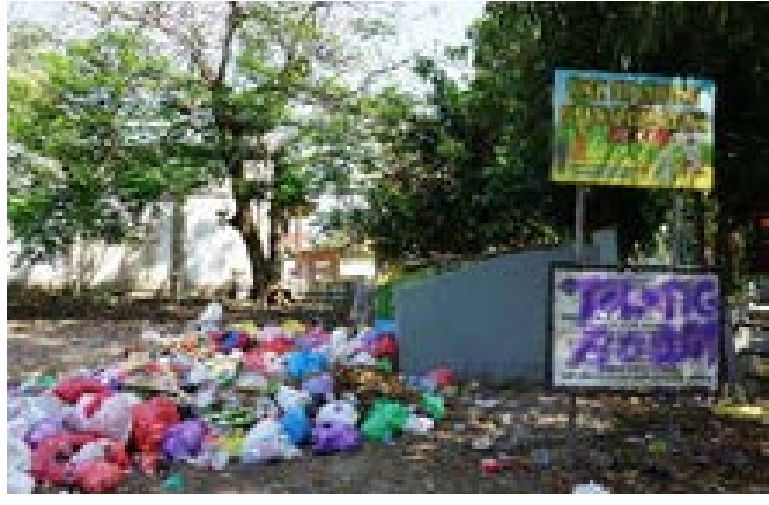

Figure 4. Pile up of Household Waste in Urban Area TPS

waste still accumulates during the day in the Terminal By-Pass area.

In urban area, the waste was indirectly collected individually. The garbage collectors transported the residents' waste using three-wheeled vehicles, while intensive services were carried out on the main roads, town center, and commercial areas. The collected waste is then transported to the TPS and TPST scattered in several areas. The district government has built a separate TPS and TPST on available land. However, the lack of community participation and/ or technical error in transportation caused the sorted waste to be mixed up and piled up at the TPS. This is consistent with the results of observations of several TPS in the urban areas. The accumulation of waste in the TPS was caused by an imbalance between waste production and the ability to process it, as well as the lack of means for collecting and transporting it (Rizal, 2011).

Government Regulation of the Republic of Indonesia No. 81 of 2012 concerning Management of Household Waste and Waste Similar to Household Waste regulated on the provision of waste management infrastructure in the settlement areas. The efforts made by the district government in reducing organic and inorganic waste were carried out by providing waste treatment facilities, one of which is the TPS3R. The definition of the TP3SR based on Government Regulation of the Republic of Indonesia No. 81 of 2012 concerning Management of Household Waste and Waste Similar to Household Waste is the place where collection, sorting, reuse, and recycling activities are carried out for an area (Government Regulation of the Republic of Indonesia No. 81 of 2012, 2012).

There were two types of waste reduction infrastructure in this area, waste banks, and the TPS3R. Based on the results of field observation, there were three waste banks and one TPS3R spread across several areas in North Tapin District. From the aforementioned infrastructures, some waste banks

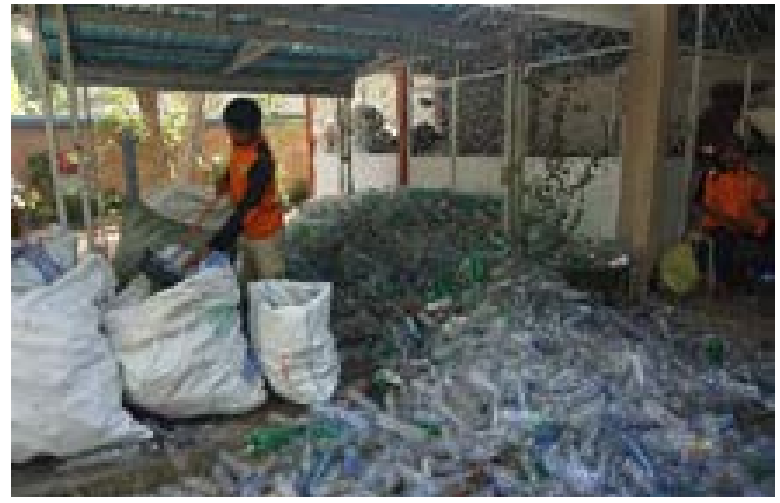

Figure 5. Processing Activities of Plastic Waste at Tapin Main Waste Bank

were actively operating, and some of them were less active, while the TPS3R was not very active. Figure 5 shows the activities at Tapin Main Waste Bank in the sorting of inorganic waste. With a total inorganic waste generation in Tapin Utara Subdistrict of 2,696 tons/year or equivalent to 7.4 tons/day, the main waste bank can manage inorganic waste originating from the unit waste bank in urban villages of Rangda Malingkung and Kupang, Adiwiyata school, and from TPS around it, with an average of 0.29 tons/day. In addition to the Tapin Main Waste Bank, the urban area has unit waste banks located in the residential areas of Rangda Malingkung and Kupang.

Activities carried out at the unit's waste bank were minimal, based on the field visit, no significant operational activities were visible. Likewise, the Go Green Bastari waste bank located in urban village of Kupang was inactive. This is because this waste bank was relatively newly established after obtaining the Special Allocation Fund (DAK) in 2017.

Waste banks based on citizen participation are social capital in community-based waste management (Asteria \& Heruman, 2016). The Go Green Bastari waste bank is managed by an institution formed to facilitate community participation in environmental management. It would manage waste from the urban village of Kupang. Based on the observation of the waste bank management, the main obstacles were the lack of participation from the surrounding population, who were not actively utilizing the waste bank to receive its benefit and save money. The lack of socialization from the government to the community and community leaders also hinder the increase of savings activity of the community.

\section{Conclusion}

Based on the results and discussion, it can be concluded that the policymaking and implementation of waste management policies are regulated in Regional Regulation No. 6 of 2015 on Waste 
Management. The regional regulation is in line with Law Number 18 on Waste Management.

The existence of the regional regulations affects the waste management in Tapin District with a direct individual and communal service system only in urban areas, having a service level of $27.2 \%$ or 25.4 tons/day from 93.3 tons/day of waste produced. Waste reduction effort by providing supporting facilities in the form of TPS3R and waste banks to reduce organic and inorganic waste are merely able to reduce 0.69 tons/day of waste with a breakdown of 0.45 tons/day of organic waste managed by TPS3R and 0.24 tons/day of inorganic waste managed by garbage banks.

The limited social carrying capacity and the lack of waste management infrastructure have led to an unsuccessful reduction of waste at the source level. A policy in the form of a program to increase the community role by using the $3 \mathrm{R}$ (reduce, reuse, recycle) concept is needed.

\section{ACKNOWLEDGMENT}

The author would like to thank the Pusat Pembinaan Pendidikan dan Pelatihan Perencana (Pusbindiklatren) Bappenas for providing the scholarships to complete this study. The author also would like to thank the Tapin District Government for providing the opportunity by granting the study permits to the author and to all parties who have provided the necessary information and data for this study.

\section{REFERENCES}

Andriyan, D. N. (2019). Content Analysis (Analisis Isi) terhadap Peraturan Daerah Bernuansa Syariat Islam di Kabupaten Banyumas. Jurnal Suara Hukum, 1(2), 121-141. https://doi. org/10.26740/1.jsh.2019.1.2.4662

Asteria, D., \& Heruman, H. (2016). Bank Sampah Sebagai Alternatif Strategi Pengelolaan Sampah Berbasis Masyarakat di Tasikmalaya. Jurnal Manusia Dan Lingkungan, 23(1), 136-141. https://doi.org/10.22146/jml.18783

BPS Indonesia. (2017). Statistik Lingkungan Hidup Indonesia 2017. BPS Indonesia. https:/ /www. bps.go.id/publication/2017/12/21/4acfbaac0328ddfcf8250475/statistik-lingkungan-hidup-indonesia-2017.html

BPS Kabupaten Tapin. (2020). Kabupaten Tapin Dalam Angka 2020. BPS Kabupaten Tapin. https://tapinkab.bps.go.id/publication/2020/04/27/3e021dc0b8bd6331a5ffe2b8/kabupaten-tapin-dalam-angka-2020. html
Damanhuri, E., \& Padmi, T. (2019). Pengelolaan Sampah Terpadu (2nd ed.). ITB Press.

DLH Kabupaten Tapin. (2018). Rencana Strategis Dinas Lingkungan Hidup Kabupaten Tapin Tahun 2013-2017. DLH Kabupaten Tapin.

DLH Kabupaten Tapin. (2020). Laporan Kinerja Instansi Pemerintah Tahun 2020. DLH Kabupaten Tapin.

Dobiki, J. (2018). Analisis Ketersediaan Prasarana Persampahan di Pulau Kumo dan Pulau Kakara di Kabupaten Halmahera Utara. Jurnal Spasial, 5(2), 220-228. https://ejournal.unsrat.ac.id/ index.php/spasial/article/view/20803

Jambeck, J. R., Geyer, R., Wilcox, C., Siegler, T. R., Perryman, M., Andrady, A., Narayan, R., \& Law, K. L. (2015). Plastic waste inputs from land into the ocean. Science, 347(6223), 768-771. https: // doi.org/10.1126/science.1260352

Jaya, M. T. B. S., Hubeis, A. V., Anwar N., K., \& Anwar, S. (2010). Kajian Kebijakan dan Program Pengelolaan Kebersihan Lingkungan Berkelanjutan Kota Bandar Lampung. Ruwa Jurai, 4(1), 20-34. http://repository.ipb.ac.id/ handle/123456789/62013

Nugraha, A. (2017). Analisis Efektivitas Pengelolaan Sampah Rumah Tangga Menggunakan Pendekatan Bank Sampah di DKI Jakarta [Bogor Agricultural University (IPB)]. http:/ / repository. ipb.ac.id/handle/123456789/91384

Paramita, D., Murtilaksono, K., \& Manuwoto, M. (2018). Kajian Pengelolaan Sampah Berdasarkan Daya Dukung dan Kapasitas Tampung Prasarana Persampahan Kota Depok. Journal of Regional and Rural Development Planning, 2(2), 104-117. https://doi.org/10.29244/ jp2wd.2018.2.2.104-117

Puspasari, G. R., \& Mussadun, M. (2016). Peran Kelembagaan dalam Pengelolaan Persampahan di Kabupaten Trenggalek. Jurnal Pembangunan Wilayah \& Kota, 12(4), 385-399. https://doi. org/10.14710/pwk.v12i4.13505

Rahman, A. (2013). Perilaku Masyarakat dalam Pengelolaan Sampah Rumah Tangga (Studi Kasus di Kelurahan Pasar Sarolangun). Jurnal Bina Praja, 5(4), 215-220. https://doi. org/10.21787/JBP.05.2013.215-220

Rizal, M. (2011). Analisis Pengelolaan Persampahan Perkotaan (Studi Kasus pada Kelurahan Boya Kecamatan Banawa Kabupaten Donggala). Jurnal SMARtek, 9(2), 155-172. http://jurnal.untad.ac.id/jurnal/index.php/SMARTEK/article/ view/614

Law No. 18 of 2008 on Waste Management, Pub. L. No. 18 (2008).

Government Regulation of the Republic of Indonesia No. 81 of 2012 concerning Management 
of Household Waste and Waste Similar to Household Waste, Pub. L. No. 81 (2012).

Seruyaningtyas, K., Handayani, D. S., \& Samadikun, B. P. (2017). Perencanaan Sistem Pengelolaan Sampah Terpadu Studi Kasus Kelurahan Gedawang Kecamatan Banyumanik, Kota Semarang. Jurnal Teknik Lingkungan, 6(1), 1-12.

Regional Regulation No. 6 of 2015 on Waste Management, Pub. L. No. 6 (2015).

Suntari, K. A., Pirngadi, B. H., \& Syarifudin, D. (2018). Tingkat Pengelolaan Sampah oleh Masyarakat di Kawasan Perkotaan Ciwidey. Jurnal Planologi Unpas, 5(1), 917-924. https://doi. org/10.23969/planologi.v5i1.929
Wahyono, S. (2018). Konsep Pengelolaan Sampah Kota dan Kaji Terap Teknologi Pengelolaannya. Prosiding Seminar Nasional Dan Konsultasi Teknologi Lingkungan, 58-64.

Widyarsana, I. M. W., \& Zafira, A. D. (2015). Kajian Pengembangan Sistem Pengelolaan Sampah di Kabupaten Tangerang. Jurnal Tehnik Lingkungan, 21(1), 87-97. https://doi.org/10.5614/ jtl.2015.21.1.10

Wirawan, S. M. S., Maarif, M. S., Riani, E., \& Anwar, S. (2018). Analysis of the Institutions Role in Sustainable Domestic Wastewater Management in Jakarta. Jurnal Bina Praja, 10(2), 303-315. https://doi.org/10.21787/jbp.10.2018.303-315 